\title{
Moderasi Kemampuan Teknik Personal dan Pelatihan terhadap Pengaruh Kecanggihan Teknologi pada Efektivitas Penggunaan SIA
}

\author{
Nyoman Notiasih ${ }^{1}$ \\ Fakultas Ekonomi dan Bisnis \\ Universitas Udayana, Indonesia
}

\author{
I Made Pande Dwiana Putra ${ }^{2}$ \\ Fakultas Ekonomi dan Bisnis \\ Universitas Udayana, Indonesia
}

\section{ABSTRAK}

Penelitian ini bertujuan umtuk menguji secara empiris moderasi kemampuan teknik personal dan pelatihan terhadap pengaruh kecanggihan teknologi pada efektivitas penggunaan sistem informasi akuntansi. Sampel yang digunakan adalah nonprobability sampling yaitu metode purposive sampling menggunakan 100 responden karyawan dan manajer di bidang department accounting menggunakan SIA lebih dari satu tahun. Teknik analisis data menggunakan uji Moderated Regression Analysis (MRA). Menghasilkan analisis bahwa kemampuan teknik personal mampu memoderasi terhadap pengaruh kecanggihan teknologi pada efektivitas penggunaan SIA, pelatihan mampu memoderasi terhadap pengaruh kecanggihan teknologi pada efektivitas penggunaan SIA dan kecanggihan teknologi berpengaruh positif pada efektivitas penggunaan SIA
\end{abstract}

Surel : notiasihh@gmail.com

Kata Kunci: Kemampuan Teknik Personal; Pelatihan; Kecanggihan Teknologi; Penggunaan Sistem Informasi Akuntansi.

\section{Moderation of Personal Engineering Ability and Training on the Effect of Technological Sophistication on the Effectiveness of the Use of AIS}

\section{ABSTRACT}

This study aims to empirically test the moderation of personal technical skills and training on the effect of technological sophistication on the effectiveness of the use of accounting information systems. The sample used is non-probability sampling, namely purposive sampling method using 100 respondents of employees and managers in the accounting department using SIA for more than one year. The data analysis technique used the Moderated Regression Analysis (MRA) test. Resulting in an analysis that the ability of personal engineering is able to moderate the effect of technological sophistication on the effectiveness of the use of SIA, training is able to moderate the effect of technological sophistication on the effectiveness of the use of SIA and technological sophistication has a positive effect on the effectiveness of using SIA.

Keywords: Personal Technical Ability; Training; Technological Sophistication; Using SIA.

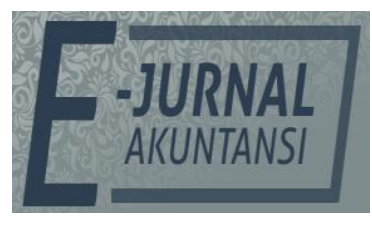

e-ISSN 2302-8556

Vol. 31 No. 9

Denpasar, September 2021 Hal. 2388-2400

DOI:

10.24843/EJA.2021.v31.i09.p19

PENGUTIPAN:

Notiasih, N., \& Putra,

I.M.P.D. (2021). Moderasi

Kemampuan Teknik Personal dan Pelatihan terhadap Pengaruh Kecanggihan Teknologi pada Efektivitas Penggunaan SIA. E-Jurnal Akuntansi, 31(9), 2388-2400

RIWAYAT ARTIKEL: Artikel Masuk: 29 Januari 2021 Artikel Diterima: 3 April 2021

Artikel dapat diakses : https://ojs.unud.ac.id/index.php/Akuntansi/index 


\section{PENDAHULUAN}

Dewasa ini, globalisasi mengakibatkan dunia teknologi komputerisasi dan informasi mengalami perkembangan yang terus-menerus meningkat. Komputer mutlak diperlukan ketika melakukan hal kegiatan pekerjaan, ditambah lagi peran sistem informasi didalam perangkat komputer sangat penting yang akan membantu memudahkan berbagai pekerjaan memungkinkan manusia untuk memperoleh data atau informasi umum dari jarak berjauhan hanya dalam waktu yang sesingkat mungkin. Pada saat ini, tanpa adanya komputer sistem informasi tidak memungkinkan akan berjalan dengan baik dan sumber teknologi pendukung lainnya tidak dapat difungsikan dengan baik. Akibatnya, sistem informasi akuntansi yang awalnya dilakukan menggunakan manual sekarang melainkan oleh komputer di berbagai kalangan perusahaan. Metode manual terdahulu tidaklah efektif karena menguras waktu yang cukup lama untuk melakukan perhitungan ulang dari awal jika terjadi kekeliruan dan perubahan laporan sehingga memerlukan waktu lebih untuk menghasilkan suatu laporan keuangan (Krahel \& Vasarhelyi, 2014). Doll \& Torkzadeh (1998) menyatakan bahwa kepuasan pengguna menggunakan beberapa konsep untuk meningkatkan efektivitas sistem informasi akuntansi. Penerapan dan pemanfaatan sistem informasi yang berbasis komputer, tidak hanya berfungsi sebagai sarana pendukung untuk meningkatkan kinerja perusahaan, tetapi telah menjadi senjata utama menghadapi persaingan maka teknologi pun menyesuaikan untuk memenuhi kebutuhan tersebut (Moqbel, 2014). Salah satu hal yang penting dalam memenangkan persaingan bisnis adalah informasi, terutama informasi keuangan suatu organisasi (Nabizadeh \& Omrani, 2014).

Berhasil atau tidaknya sistem informasi suatu perusahaan bergantung kepada bagaimana sistem itu dijalankan. Maka dari itu, diperlukan adanya kecanggihan teknologi dalam suatu perusahaan. Kecanggihan teknologi di masa kini memiliki perkembangan yang pesat bahkan mampu menghasilkan beraneka ragam teknologi sistem yang dirancang untuk membantu pekerjaan manusia dalam menghasilkan kualitas informasi terbaik. Ketika mengimplementasikan teknologi tersebut, maka harus diadakan pelatihan pada pengguna teknologi terkait sangatlah diperlukan agar penggunanya mampu mengoperasikan sistem yang dimiliki oleh perusahaan dengan baik, akurat dan tepat waktu. Dalam menggunakan sistem informasi pada perusahaan pada saat ini membantu dalam menerima, memproses, menyimpan dan mengirimkan data dengan bantuan komputer. Salah satu usaha perhotelan di Bali yang konsisten dalam mempertahankan, dan mengembangkan kapasitas, dan kapabilitas sebagai leading stars hotel in Bali adalah Inna Hotel Group Bali. Kelompok hotel yang bergabung dalam Inna Group di bawah pengelolaan PT. Hotel Indonesia Natour, merupakan sekelompok hotel-hotel milik pemerintah yang pertama kali berdiri mengawali sejarah kepariwisataan, dan perhotelan di Indonesia, khususnya di Bali yaitu Inaya Putri Bali, Inna Grand Bali Beach, Inna Bali Heritage, Inna indhu Beach dan Grand Inna Kuta. Serta merupakan kawasan strategis karena dekat dengan pantai, pusat bisnis, pusat perbelanjaan dan objek wisata. Hal ini memberikan daya tarik tersendiri di mata wisatawan.

Banyaknya fenomena yang terjadi yaitu pengguna sistem informasi pada perusahaan yang terus berkembang menyebabkan peningkatan kerumitan 
kegiatan pelaporan dalam sistem infomasi akuntansi, terutama proses pengumpulan data keuangan organisasi dari mencakup sistem yang mudah untuk dipahami hingga tingkat kerumitan yang lebih tinggi, hal tersebut dapat menyebabkan pengguna merasakan kelelahan sehingga berdampak pada ketelitian dalam menyelesaikan pekerjaan. Diperlukan penerapan teknologi sebagai suatu keberhasilan kualitas, kuantitas, dan waktu yang digunakan dan hasil kerja yang telah dicapai dalam kegiatan keuangan organisasi untuk mempermudah penyelesaian pekerjaan, yaitu sistem informasi terkomputerisasi.

Menyikapi kondisi tersebut, maka perusahaan harus memiliki sistem informasi akuntansi yang mampu menangkap peluang dari peningkatan transaksi online. Sistem informasi akuntansi yang baik dapat menunjang efektivitas penjualan, serta miningkatkan efisiensi operasi perusahaan dan mendorong ditaatinya kebijakan yang ditetapkan oleh perusahaan. Kemampuan teknik personal dalam mengoperasikan sistem informasi akuntansi sangat penting dalam hal pengoperasian sistem agar dapat berjalan secara maksimal (Putri, 2015). Menurut (Ruth, 2018), kemampuan teknik personal sangat dibutuhkan, dimana kemampuan teknik personal akan menunjukkan sejauh mana kualitas pribadi seseorang dalam mengoperasikan sebuah sistem akuntansi. Dalam teori TAM kemampuan teknik personal berkaitan dengan persepsi kemudahan (ease of use) dimana kemampuan teknik personal yang tinggi akan berujung pada tingkat kepercayaan yang tinggi terhadap kemudahan pemakaian sistem (D. Davis, 1985) Pengimplementasian teknologi sistem informasi membutuhkan diadakannya pelatihan pada penggunanya agar mampu mengoperasikan sistem dengan baik, akurat dan cepat. Pelatihan akan meningkatkan kemampuan karyawan sehingga akan membantu penyelesaian pekerjaan yang akan berujung pada tercapainya visi dan misi organisasi perusahaan.

Dalam kerangka teori TAM, pelatihan berkaitan dengan persepsi kemudahan (ease of use) dimana pelatihan akan berujung pada tingkat kepercayaan yang tinggi terhadap kemudahan pemakaian sistem. Kemampuan teknik personal dan pelatihan pada kecanggihan teknologi efektivitas penggunaan sistem informasi akuntansi ditemukan hasil yang variatif atau tidak konsisten atau masih kontroversi yang diduga karena adanya faktor lain yang mempengaruhi hubungan antara variabel bebas dengan variabel terikat. Govindarajan \& Gupta (1985) menyatakan bahwa kemungkinan belum adanya kesatuan hasil penelitian tergantung faktor-faktor tertentu atau lebih dikenal dengan istilah faktor kontinjensi. Agar dapat merekonsiliasi hasil yang saling bertentangan diperlukan pendekatan kontingensi untuk mengindentifikasi variabel lain yang bertindak sebagai pemoderasi ataupun pemediasi dalam model riset. Beberapa riset empiris yang relevan dengan penelitian ini telah banyak dilakukan sebelumnya. Hasil penelitian Suartika et al., (2017), Puspitasari (2017), dan Ardiwinata (2019) menemukan hubungan yang positif antara kemampuan teknik personal dengan efektivitas penggunaan sistem informasi akuntansi. Perbedaan hasil ditunjukkan pada penelitian Dharmawan \& Ardianto (2017) menyatakan kemampuan teknik personal memiliki pengaruh negatif terhadap kinerja efektivitas sistem informasi. Maka penelitian ini menggunakan kemampuan teknik personal, dan pelatihan sebagai variabel moderasi 
Berdasarkan paparan penelitian pengaruh penggunaan teknologi informasi pada efektivitas sistem infomasi akuntansi ditemukan hasil yang variatif atau tidak konsisten masih kontroversi yang diduga karena adanya faktor lain yang mempengaruhi hubungan antara kemampuan teknik personal dan pelatihan. Hasil-hasil penelitian sebelumnya yaitu penelitian dari Ismail (2009) menyatakan bahwa kecanggihan sistem informasi akuntansi tidak berpengaruh Signifikan terhadap efektivitas sistem informasi akuntansi. Perbedaan hasil didapat dari penelitian Dwitrayani et al., (2017) dan Ratnaningsih \& Suaryana (2014) yang menyatakan bahwa kecanggihan teknologi informasi berpengaruh positif dan Signifikan terhadap efektivitas sistem informasi akuntansi. Maka penelitian penelitian ini menggunakan kecanggihan teknologi sebagai variabel bebas, karena dengan adanya kualitas sistem yang sangat mutakhir akan memudahkan pengguna untuk mengerjakan pekerjaannya serta akan menghasilkan kualitas informasi yang baik, akurat, dan efisien, dari hal tersebut akan meningkatkan efektivitas pekerja dalam menggunakan sistem informasi. Pentingnya penerapan atau penggunaan sistem informasi akuntansi dan teknologi informasi untuk mengetahui efektivitas dan kondisi ekonomi perusahaan (Dwirandra \& Astika, 2020).

Alasan pengambilan objek penelitian memilih hotel sebagai lokasi penelitian. Hotel merupakan salah satu jenis akomodasi yang sangat dikenal oleh masyarakat di samping akomodasi komersil lainnya. Sebagai suatu industri jasa, usaha perhotelan dalam menyelenggarakan pelayanannya harus didukung oleh sarana dan fasilitas yang memadai, termasuk juga sarana dan prasarana dalam mendukung efektivitas sistem informasi akuntansi hotel. Teknologi informasi di dalam industri perhotelan merupakan hal yang sangat penting. Teknologi informasi yang digunakan harus sesuai dengan visi, misi, dan tujuan dari hotel tersebut. Berbeda dengan penelitian sebelumnya, yang telah dilakukan oleh beberapa peneliti mengenai efektivitas sistem infomasi akuntansi, dalam penelitian ini dipilih hotel sebagai lokasi penelitian. Diharapkan dari penelitian ini dapat diketahui efektivitas penggunaan sistem informasi akuntansi di Hotel Inna Group Bali. penelitian ini mencoba untuk mengetahui kemampuan moderasi dua faktor kontingensi (kemampuan teknik personal dan pelatiahan) terhadap pengaruh kecanggihan teknologi pada efektivitas sistem informasi akuntansi.

Berdasarkan teori TAM, persepsi kemudahan (Perceived ease to use) yang telah dijelaskan pada penelitian Davis (1985), bahwa sejauh mana pengguna percaya menggunakan teknologi merupakan hal yang mudah dan tidak memerlukan usaha yang lebih besar pada saat digunakan, dengan adanya teknologi di masa kini yang semakin canggih dan beragam, memiliki tujuan untuk mempermudah manusia dalam bekerja (Putra, 2021). Hubungan kecanggihan teknologi informasi dan efektivitas sistem informasi akuntansi dapat dijelaskan dengan pemikiran bahwa sistem yang memiliki kecanggihan informasional yang baik akan membantu perusahaan menghasilkan informasi yang cepat dan akurat untuk pembuatan keputusan yang efektif (Huber, 1990). Semakin canggih sebuah teknologi maka pemakaian teknologi akan semakin mudah, hal tersebut dapat dilihat dari perancangan teknologi dimana semakin mutakhir teknologi semakin user-friendly karena teknologi ditujukan untuk membantu pekerjaan manusia 
sehingga dirancang untuk semakin mudah digunakan hal itu dapat dilihat dari kecepatan pemrosesan data dan output yang dihasilkan semakin baik jika teknologi yang digunakan semakin canggih.

Hasil penelitian yang dilakukan oleh Dwitrayani et al., (2017) menghasilkan bahwa kecanggihan teknologi informasi memiliki pengaruh Signifikan dengan efektivitas sistem informasi akuntansi. Hal tersebut konsisten dengan hasil penelitian yang telah dilakukan oleh Ratnaningsih \& Suaryana (2014), Rokhman (2016), dan Seviani (2017) dengan kata lain kecanggihan teknologi akan mampu memberikan pengaruh yang baik pada efektivitas sistem informasi akuntansi. Berdasarkan uraian tersebut dapat dirumuskan hipotesis pertama yang akan diuji yaitu sebagai berikkut.

$\mathrm{H}_{1}$ : Kecanggihan teknologi berpengaruh positif pada efektivitas penggunaan sistem informasi akuntansi.

Technology Acceptance Model (TAM) menjelaskan bahwa terdapat dua faktor yang mempengaruhi sikap individu untuk menerima dan menggunakan teknologi, yaitu manfaat dan kemudahan (D. Davis, 1985). Berdasarkan pemaparan teori TAM, maka Kemampuan teknik personal pemakai sistem informasi berperan penting dalam pengembangan sistem informasi akuntansi untuk dapat membuat laporan perencanaan yang akurat. Oleh karena itu, setiap karyawan harus dapat menguasai penggunaan sistem berbasis computer agar dapat memproses sejumlah transaksi dengan cepat dan terintegrasi, dapat menyimpan data dan mengambil data dalam jumlah yang besar, dapat mengurangi kesalahan matematik, menghasilkan laporan tepat waktu dalam berbagai bentuk, serta dapat menjadi alat bantu dalam mengambil keputusan.

Hasil penelitian Yesa (2016) Abhimantra \& Suryanawa (2016) dan Adisanjaya (2017) menyatakan kemampuan teknik personal berpengaruh positif dan Signifikan terhadap kinerja SIA dengan tempat penelitian yang berbeda. Perbedaan hasil terjadi pada penelitian Dharmawan \& Ardianto (2017) yang menghasilkan bahwa kemampuan teknik personal berpengaruh negatif pada efektivitas SIA. Maka dengan adanya perbedaan hasil penelitian sebelumnya, membuat peneliti untuk menggunakan kemampuan teknik personal sebagai variabel pemoderasi, karena dengan adanya kemampuan teknik personal yang baik akan menunjukkan sejauh mana kualitas pribadi seseorang dalam menguasai teknik pengelolaan sistem informasi akuntansi yang dikembangkan, maka guna untuk menciptakan laporan perencanaan yang akurat karyawan dituntut untuk menguasai penggunaan sistem informasi akuntansi berbasis komputer agar memudahkan dalam pelaksanaanya. Oleh karena itu kemampuan teknik personal akan mampu memoderasi efektivitas SIA. Maka dapat dirumuskan hipotesis kelima yang akan diuji sebagai berikut.

$\mathrm{H}_{2}$ : Kemampuan teknik personal memoderasi pengaruh kecanggihan teknologi pada efektivitas penggunaan sistem informasi akuntansi.

Technology Acceptance Model (TAM) menjelaskan bahwa terdapat dua faktor yang mempengaruhi sikap individu untuk menerima dan menggunakan teknologi, yaitu manfaat dan kemudahan (Davis, 1985). Manfaat dari adanya teknologi itu sendiri dapat dirasakan apabila pengguna sudah mampu mengoperasikannya. Program pelatihan merupakan kegiatan yang diselenggarakan oleh pihak perusahaan guna memperkenalkan sistem informasi 
yang digunakan. Pelatihan meningkatkan pengetahuan dan kemampuan karyawan dalam melaksanakan pekerjaanya lebih efektif dan efisien. Pelatihan kerja merupakan sebuah proses mengajarkan pengetahuan dan keahlian tertentu serta sikap, agar karyawan semakin terampil dan mampu melaksanakan tanggung jawabnya dengan semakin baik serta sesuai dengan standar. Diawali dari pelatihan, menurut Masadeh (2012) pelatihan merupakan proses yang telah direncanakan untuk memodifikasi perilaku sikap, pengetahuan serta keahlian individu melalui pengalaman belajar yang intens demi mendapatkan kinerja yang kebih efektif dalam berbagai aktivitas atau kegiatan.

Hasil penelitian Suartika et al., (2017) menyatakan bahwa pendidikan dan pelatihan memperkuat pengaruh kemampuan teknik personal terhadap efektivitas penggunaan SIA. Hasil bahwa pendidikan dan pelatihan tidak mampu memoderasi pengaruh keterlibatan pemakai pada kinerja SIA. Peneliti Puspitasari (2017) juga menemukan hasil bahwa pendidikan dan pelatihan mampu memoderasi pengaruh kemampuan teknik personal pada kinerja SIA. Pelatihan bagi penggunanya merupakan faktor yang penting untuk pengembangan sistem. Semakin sering diadakannya pelatihan untuk pemakai, diharapkan akan membuat pengguna dalam menjalankan sistem informasi akuntansi menjadi lebih baik dan efektif. Berdasarkan uraian tersebut dapat dirumuskan hipotesis ketiga yang akan diuji yaitu sebagai berikut.

$\mathrm{H}_{3}$ : Pelatihan memoderasi pengaruh kecanggihan teknologi pada efektivitas penggunaan sistem informasi akuntansi.

\section{METODE PENELITIAN}

Metode pengumpulan data primer ini dilakukan dengan menggunakan kuesioner yang dibagikan kepada setiap responden. Kuesioner yang dibagikan menggunakan google form yang dibagikan oleh manajer melalui group whatsapp di Hotel Inna Group Bali yang menggunakan sistem informasi akuntansi. Populasi dalam penelitian ini pada karyawan dan manajer department accounting di Hotel Inna Group Bali yang menggunakan sistem informasi akuntansi. Teknik penentuan sampel yang dipilih adalah non-probability sampling dengan metode purposive sampling dengan tujuan untuk mendapatkan sampel yang sesuai dengan kriteria yang ditentukan. Kriteria sampel adalah karyawan yang bekerja langsung menggunakan SIA dan telah menggunakan SIA selama minimal 1 tahun.

Teknik yang diguakan dalam penelitian ini adalah uji interaksi yang sering disebut dengan Moderated Regression Analysis (MRA) yang merupakan aplikasi khusus regresi linear berganda, dimana dalam persamaan regresinya mengandung unsur interaksi (perkalian dua atau lebih variabel independen). Teknik analisis ini dipilih karena penelitian ini dirancang untuk meneliti variabel independen yang berpengaruh terhadap variabel dependen dengan menggunakan variabel pemoderasi. Model regresi dalam penelitian ini ditunjukkan dengan persamaan sebagai berikut.

$\hat{Y}=\alpha+\beta_{1} X+\beta_{2} M_{1}+\beta_{3} M_{2}+\beta_{4} X . M_{1}+\beta_{5} X . M_{2}+\varepsilon$

Keterangan:

$\mathrm{Y}=$ Efektivitas Penggunaan Sistem Informasi Akuntansi

a $\quad=$ Konstanta

$\mathrm{X} \quad=$ Kecanggihan Teknologi 


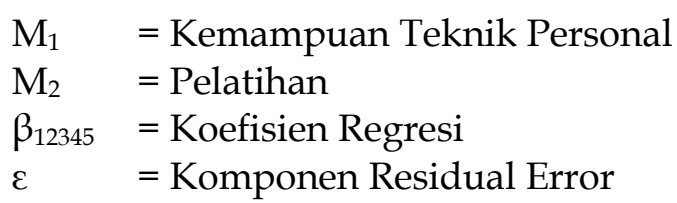

\section{HASIL DAN PEMBAHASAN}

Uji validitas dilakukan dengan menghitung korelasi antara skor tiap butir pernyataan pada kuisiner dengan skor totalnya menggunakan program bantuan SPSS sehingga diperoleh Pearson Correlation dapat disimpulkan bahwa instrumen yang digunakan pada penelitian ini telah valid dan dapat digunakan karena memiliki nilai Pearson Correlation lebih dari 0,3 . Suatu variabel dikatakan reliabel atau handal jika jawaban yang diberikan terhadap pernyataan bersifat stabil dan konsisten dari waktu ke waktu (Ghozali, 2016:47). Instrumen penelitian memiliki nilai Cronbach's alpha lebih besar dari 0,7 sehingga pernyataan dalam kuesioner reliabel. Statistik deskriptif dalam penelitian ini digunakan untuk memberikan informasi mengenai karakteristik variabel-variabel penelitian, antara lain nilai minimum, maksimum, rata-rata, standar deviasi dengan $\mathrm{N}$ adalah banyaknya responden penelitian. Hasil statistik deskriptif dapat dilihat pada Tabel 1, berikut. Tabel 1. Hasil Uji Statistik Deskriptif

\begin{tabular}{lcccccc}
\hline \multicolumn{1}{c}{ Variabel } & N & Min & Max & Mean & $\begin{array}{c}\text { Std. } \\
\text { Deviaton }\end{array}$ & $\begin{array}{c}\text { Skor rata- } \\
\text { rata }\end{array}$ \\
\hline Kemampuan Teknik Personal & 100 & 14,000 & 20,000 & 17,390 & 1,734 & 4,347 \\
Pelatihan & 100 & 14,000 & 20,000 & 17,810 & 1,790 & 4,452 \\
Kecanggihan Teknologi & 100 & 14,000 & 20,000 & 17,260 & 1,685 & 4,315 \\
Efektivitas Sistem Informasi & 100 & 22,000 & 30,000 & 26,540 & 2,208 & 4,423 \\
Akuntansi & & & & & & \\
Valid N (listwise) & 100 & & & & & \\
\hline
\end{tabular}

Sumber: Data Penelitian, 2021

Berdasarkan Tabel 1, menunjukkan hasil bahwa statistik deskriptif dari setiap variabel, jumlah sampel yang digunakan dalam penelitian ini adalah 100 . Berikut adalah penjelasan statistik deskriptif dari setiap variabel.

Variabel Kemampuan Teknik Personal memiliki nilai terendah (minimum) 14,000 dan nilai tertinggi (maksimum) sebesar 20,000 dengan nilai skor rata-rata 4,347 untuk variabel kemampuan teknik personal yang berarti lebih mendekati nilai 4 atau tergolong setuju atau baik. Variabel Pelatihan memiliki nilai terendah (minimum) 14,000 dan nilai tertinggi (maksimum) sebesar 20,000 dengan nilai skor rata-rata 4,452 untuk variabel pelatihan yang berarti lebih mendekati nilai 4 atau tergolong setuju atau baik.

Variabel Kecanggihan Teknologi memiliki nilai terendah (minimum) 14,000 dan nilai tertinggi (maksimum) sebesar 20,00 dengan nilai skor rata-rata 4,315 untuk variabel kecanggihan teknologi yang berarti lebih mendekati nilai 4 atau tergolong setuju atau baik. Variabel Efektivitas Penggunaan SIA memiliki nilai terendah (minimum) 22,000 dan nilai tertinggi (maksimum) sebesar 30,000 dengan nilai skor rata-rata 4,423 untuk variabel efektivitas penggunaan SIA yang berarti lebih mendekati nilai 4 atau tergolong setuju atau baik.

Berdasarkan hasil uji normalitas diperoleh nilai Signifikan sebesar 0,089 yang lebih besar dari 0,05 , Hasil uji normalitas dengan model regresi 
menunjukkan bahwa nilai residual berdistribusi normal sehingga dikatakan layak untuk diuji. Berdasarkan hasil uji multikolinearitas untuk variabel kecanggihan teknologi $(\mathrm{X})$ diperoleh nilai Tolerance 0,826 , variabel kemampuan teknologi $\left(\mathrm{M}_{1}\right)$ diperoleh nilai Telerance 0,857 dan variabel pelatihan $\left(\mathrm{M}_{2}\right)$ diperoleh nilai Tolerance 0,935 . Untuk setiap variabel lebih besar dari 10 persen atau 0,1 dan nilai VIF lebih kecil dari 10 sehingga dapat disimpulkan pada model regresi tidak adanya korelasi antara variabel bebas atau tidak terjadi multikoniearitas. Hasil Uji Heteroskedastisitas menunjukkan bahwa nilai Signifikansi variabel bebas memiliki nilai Sig.> 0,05 sehingga dapat disimpulkan bahwa model regresi dalam penelitian ini bebas dari gejala heteroskedastisitas.

Moderated Regression Analysis (MRA) merupakan aplikasi khusus regresi linear berganda dimana dalam persamaan regresinya mengandung unsur interaksi (perkalian dua atau lebih variabel independen), teknik analisis ini digunakan karena pada penelitian ini dirancang untuk meneliti variabel independen yang berpengaruh terhadap variabel dependen dengan menggunakan variabel moderasi diperoleh hasil yang ditunjukkan pada Tabel 2, berikut.

Tabel 2. Hasil Analisis Regresi Moderasi

\begin{tabular}{llccccc}
\hline & & \multicolumn{2}{c}{$\begin{array}{c}\text { Unstandardized } \\
\text { Coefficients }\end{array}$} & $\begin{array}{c}\text { Standardized } \\
\text { Coefficients }\end{array}$ & & \\
\cline { 2 - 4 } \multicolumn{1}{c}{ Model } & $\mathrm{B}$ & Std. Error & Beta & $\mathrm{t}$ & Sig. \\
\hline 1 & $\begin{array}{l}\text { (Constant) } \\
\text { Kecanggihan Teknologi }\end{array}$ & 0,182 & 0,073 & 0,247 & 2,489 & 0,015 \\
& $\begin{array}{l}\text { Kemampuan Teknik } \\
\text { Personal }\end{array}$ & $-0,026$ & 0,049 & $-0,037$ & $-0,531$ & 0,597 \\
& & & & & \\
& Pelatihan & 0,300 & 0,047 & 0,389 & 6,366 & 0,000 \\
& $\mathrm{XM}_{1}$ & 0,006 & 0,003 & 0,229 & 2,126 & 0,036 \\
$\mathrm{XM}_{2}$ & 0,008 & 0,003 & 0,316 & 2,918 & 0,004 \\
\hline
\end{tabular}

Sumber: Data Penelitian, 2021

Berdasarkan Tabel 2, dapat disusun persamaan regresi sebagai berikut. $\hat{\mathrm{Y}}=14,281+0,182 \mathrm{X}-0,026 \mathrm{M}_{1}+0,300 \mathrm{M}_{2}+0,006 \mathrm{X} \cdot \mathrm{M}_{1}+0,008 \mathrm{X} \cdot \mathrm{M}_{2}$

Nilai konstanta ( $\alpha$ ) sebesar 14,281 menunjukkan bahwa apabila variabel kecanggihan teknologi $(X)$, kemampuan teknik personal $\left(\mathrm{M}_{1}\right)$, pelatihan $\left(\mathrm{M}_{2}\right)$, kecanggihan teknologi dengan kemampuan teknik personal $\left(\mathrm{X}_{\mathrm{N}} \mathrm{M}_{1}\right)$, dan kecanggihan teknologi dengan pelatihan $\left(\mathrm{X}_{\mathrm{N}} \mathrm{M}_{2}\right)$ sama dengan nol, maka efektivitas penggunaan sistem informasi akuntansi akan meningkat sebesar 14,281 satuan. Nilai konstanta bernilai positif yang berarti diperlukan kemampuan teknik personal, pelatihan dan kecanggihan teknologi untuk meningkatkan efektivitas penggunaan sistem informasi akuntansi akan meningkat.

Nilai koefisien $\beta_{1}=0,182$ menunjukkan apabila kecanggihan teknologi $(X)$ bertambah 1 (satu) satuan, maka nilai dari efektivitas penggunaan sistem informasi akuntansi (Y) akan meningkat sebanyak 0,182 satuan dengan asumsi variabel lainnya konstan. Hal ini semakin sistem yang memiliki kecanggihan teknologi yang baik maka efektivitas penggunaan sistem informasi akuntansi semakin meningkat. 
Nilai koefisien $\beta_{2}=-0,026$ menunjukkan apabila kemampuan teknik personal $\left(\mathrm{M}_{1}\right)$ bertambah 1 (satu) satuan, maka nilai dari efektivitas penggunaan sistem informasi akuntansi $(Y)$ akan menurun sebesar $-0,026$ satuan dengan asumsi variabel lainnya konstan. Hal ini berarti apabila seseorang memiliki kemampuan teknik personal yang semakin tinggi maka efektivitas penggunaan sistem informasi akuntansi semakin menurun.

Nilai koefisien $\beta_{3}=0,300$ menunjukkan apabila pelatihan $\left(\mathrm{M}_{2}\right)$ bertambah 1 (satu) satuan, maka nilai dari efektivitas penggunaan sistem informasi akuntansi (Y) akan meningkat sebanyak 0,300 satuan dengan asumsi variabel lainnya konstan. Hal ini berarti semakin baik pelatihan maka efektivitas penggunaan sistem informasi akuntansi semakin meningkat.

Nilai koefisien $\beta_{4}=0,006$ menunjukkan apabila nilai interaksi kecanggihan teknologi dengan kemampuan teknik personal (X.M1) bertambah 1 (satu) satuan, maka nilai dari efektivitas penggunaan sistem informasi akuntansi (Y) akan mengalami peningkatan sebesar 0,006 satuan dengan asumsi variabel lainnya konstan. Hal ini berarti apabila kecanggihan teknologi dan kemampuan teknik personal meningkat maka efektivitas penggunaan sistem informasi akuntansi semakin meningkat.

Nilai koefisien $\beta_{5}=0,008$ menunjukkan apabila nilai interaksi kecanggihan teknologi dengan pelatihan $\left(\mathrm{X} . \mathrm{M}_{2}\right)$ bertambah 1 (satu) satuan, maka nilai dari efektivitas penggunaan sistem informasi akuntansi (Y) akan mengalami peningkatan sebesar 0,008 satuan dengan asumsi variabel lainnya konstan. Hal ini berarti apabila kecanggihan teknologi dan pelatihan meningkat maka efektivitas penggunaan sistem informasi akuntansi semakin meningkat. Uji $\mathrm{F}$ digunakan untuk mengetahui kelayakan dari model regresi sebagai alat analisis yang menguji pengaruh variabel bebas terhadap variabel terikat. Hasil uji F dalam penelitian ini dapat dilihat pada Tabel 3, berikut.

Tabel 3. Hasil Uji Kelayakan Model

\begin{tabular}{llccccc}
\hline Model & & Sum of Squares & Df & Mean Square & F & Sig. \\
\hline 1 & Regression & 164,028 & 5 & 32,806 & 4305,059 & $0,000^{\mathrm{b}}$ \\
& Residual & 0,716 & 94 & 0,008 & & \\
& Total & 164,744 & 99 & & & \\
\hline
\end{tabular}

Sumber: Data Penelitian, 2021

Berdasarkan hasil uji kelayakan model (Uji F) pada Tabel 3, dapat dilihat bahwa nilai Signifikansi sebesar 0,000 lebih kecil dari 0,05. Sehingga dapat disimpulkan bahwa model regresi Moderated Regression Analysis dalam penelitian ini layak untuk digunakan.

Tabel 4. Hasil Uji Koefisien Determinasi

\begin{tabular}{lcccc}
\hline Model & $\mathrm{R}$ & $R$ Square & Adjusted $R$ Square & $\begin{array}{c}\text { Std. Error of the } \\
\text { Estimate }\end{array}$ \\
\hline 1 & $0,998^{\mathrm{a}}$ & 0,996 & 0,995 & 0,087
\end{tabular}

Sumber: Data Penelitian, 2021

Koefisien determinasi $\left(\mathrm{R}^{2}\right)$ digunakan untuk mengetahui dan mengukur kemampuan model dalam menerangkan variasi variabel independen peneliti menggunakan nilai adjusted $\mathrm{R}^{2}$ pada saat mengevaluasi yang mana model regresi terbaik, karena tidak seperti $\mathrm{R}^{2}$, nilai adjusted $\mathrm{R}^{2}$ dapat naik atau turun apabila satu 
variabel independen ditambahkan ke dalam model. Hasil uji koefisien determinasi dapat dilihat pada Tabel 4 .

Berdasarkan Tabel 4, hasil uji memberikan hasil dimana diperoleh besarnya adjusted $\mathrm{R}^{2}$ sebesar 0,995 atau 99,5 persen menunjukkan bahwa 99,5 persen variabel efektivitas penggunaan sistem informasi akuntansi disebabkan oleh variabel kecanggihan teknologi, dan sisanya sebesar 0,5 persen disebabkan oleh faktor lainnya. Uji $\mathrm{t}$ dipergunakan untuk menguji pengaruh dari variabel moderasi kemampuan teknik personal dan pelatihan terhadap pengaruh kecanggihan teknologi pada efektivitas penggunaan sistem informasi akuntansi menggunakan aplikasi SPSS diperoleh hasil analisis sebagai berikut. Pengaruh kecanggihan teknologi pada efektivitas penggunaan sistem informasi akuntansi berdasarkan hasil uji $t$ dengan kriteria $\mathrm{H}_{1}$ diterima jika $\beta_{1}>0$ dan Signifikansi $\beta_{1}<0,05$, diketahui bahwa variabel kecanggihan teknologi diperoleh hasil nilai koefisien 0,182 > 0 dan nilai Signifikansi 0,015 < 0,05 mengindikasikan bahwa dengan demikian $\mathrm{H}_{1}$ diterima karena kecanggihan teknologi berpengaruh positif terhadap efektivitas penggunaan sistem informasi akuntansi.

Kemampuan teknik personal memoderasi pengaruh kecanggihan teknologi pada efektivitas penggunaan sistem informasi akuntansi berdasarkan hasil uji $t$ dengan kriteria $\mathrm{H}_{2}$ diterima jika $\beta_{4}>0$ dan Signifikansi $\beta_{4}<0,05$ diketahui bahwa variabel kecanggihan teknologi dengan kemampuan teknik personal (X.M $)$ diperoleh hasil nilai koefisien 0,006 $>0$ dan nilai Signifikansi 0,036 $<0,05$ mengindikasikan $\mathrm{H}_{2}$ diterima karena hal ini berarti variabel kemampuan teknik personal mampu memoderasi dalam hubungan kecanggihan teknologi dengan efektivitas penggunaan sistem informasi akuntansi. Tabel 4, klasifikasi variabel moderasi bahwa kemampuan teknik personal merupakan tipe moderasi murni (pure moderator). Jenis moderasi pure moderator merupakan variabel yang memoderasi hubungan antara variabel independen dan variabel dependen dimana variabel moderasi murni berinteraksi dengan variabel independen tanpa menjadi variabel independen. Hasil analisis regresi moderasi menunjukkan bahwa nilai koefisien regresi variabel kemampuan teknik personal merupakan variabel moderasi yang mampu memperkuat perangaruh kecanggihan teknologi pada efektivitas penggunaan sistem informasi akuntansi.

Pelatihan memoderasi pengaruh kecanggihan teknologi pada efektivitas penggunaan sistem informasi akuntansi berdasarkan hasil uji t dengan kriteria $\mathrm{H}_{3}$ diterima jika $\beta_{5}>0$ dan Signifikansi $\beta_{5}<0,05$, diketahui bahwa variabel kecanggihan teknologi dengan pelatihan $\left(\mathrm{X}_{\mathrm{N}} \mathrm{M}_{2}\right)$ di peroleh hasil nilai koefisien 0,008 > 0 dan nilai Signifikansi 0,004 < 0,05 mengindikasikan bahwa dengan demikian $\mathrm{H}_{3}$ diterima karena hal ini berarti variabel pelatihan dapat memoderasi dalam hubungan kecanggihan teknologi dengan efektivitas penggunaan sistem informasi akuntansi. Hal ini mengindikasikan variabel moderasi merupakan tipe moderasi semu (Quasi Moderator). Jenis moderasi quasi moderator merupakan merupakan variabel yang memoderasi hubungan antara variabel independen dengan variabel dependen yang sekaligus menjadi variabel independen. Hasil analisis regresi moderasi menunjukkan bahwa nilai koefisien regresi variabel pelatihan merupakan variabel moderasi yang memperkuat perangaruh kecanggihan teknologi pada efektivitas penggunaan sistem informasi akuntansi. 


\section{SIMPULAN}

Kecanggihan teknologi berpengaruh positif terhadap efektivitas penggunaan sistem informasi akuntansi. Hal ini berarti sistem yang memiliki kecanggihan teknologi yang baik akan membantu perusahaan menghasilkan informasi yang cepat dan akurat untuk membuat keputusan yang efektif dan meningkatan efektivitas penggunaan SIA. Kemampuan teknik personal mampu memoderasi (memperkuat) terhadap pengaruh kecanggihan teknologi pada efektivitas penggunaan sistem informasi akuntansi. Hal ini berarti adanya kemampuan teknik personal akan membantu pemakai untuk menciptakan laporan yang akurat, sehingga semakin tinggi tingkat kemampuan teknik personal maka efektivitas penggunaan sistem semakin meningkat. Pelatihan mampu memoderasi (memperkuat) terhadap pengaruh kecanggihan teknologi pada efektivitas penggunaan sistem informasi akuntansi. Dengan semakin sering diadakannya pelatihan, maka semakin baik karyawan tersebut dalam menggunkan teknologi untuk menghasilkan informasi akuntansi yang berkualitas.

Hasil penelitian ini diharapkan dapat memberikan masukan terhadap pihak hotel atau perusahaan. Kecanggihan teknologi informasi khususnya pengguna komputer yang didukung dengan jaringan internet harus selalu ditingkatkan. Pengguna dan pemelihara teknologi informasi harus selalu diperhatikan agar memudahkan pekerjaan pegawai dan mengurangi kelemahan-kelemahan yang mungkin terjadi. Dimana harus lebih memperhatikan kemampuan teknik personal pemakai, dengan cara memberikan masukan pada setiap karyawan agar dapat menguasai penggunaan sistem berbasis komputer, dan pada saat melakukan pelaporan keuangan pemakai bisa lebih akurat dalam melaporkan keuangannya kepada pemilik perusahaan. Pelatihan sebaiknya diikuti secara konsisten oleh karyawan Hotel Inna Group Bali, untuk mengurangi ketidakpahaman karyawan dalam mengoperasikan sistem informasi akuntansi. Disamping itu, karyawan yang memiliki kemampuan terkait dengan sistem informasi akuntansi agar dilibatkan secara optimal dalam proses pengembangan sistem.

\section{REFERENSI}

Abhimantra, W. P., \& Suryanawa, I. K. (2016). Analisis Faktor-Faktor Yang Memengaruhi Kinerja Sistem Informasi Akuntansi. E-Jurnal Akuntansi UniversitasUdayana,14 1782-1809. https://ojs.unud.ac.id/index.php/Akuntansi/article/view/15022

Adisanjaya, K. (2017). Efektivitas Sistem Informasi Akuntansi Pada Mini Market. $7(1)$.

Al-Eqab, M., \& Adel, D. (2013). The impact of IT sophistications on the perceived usefulness of accounting information characteristics among Jordanian listed companies. International Journal of Business and Social Science, 4(3), 145-155.

Chloe, J.M. (1996). The Relationship Among Performance Of Accounting Information System, Influence Factors, And Evolution Level Of Information Systems., Journal Of Management Information System, 12(4), pp.215-239.

D. Davis, J. (1985). A Technology Acceptance Model For Empirically Testing New End-User Information Systems: Theory And Results. Science, 146(3652), 
1648-1655. https://doi.org/10.1126/science.146.3652.1648

Dharmawan, J., \& Ardianto, J. (2017). Pengaruh Kemutakhiran Teknologi, Kemampuan Teknik Personal Sistem Informasi, Program Pelatihan Pengguna Dan Dukungan Manajemen Puncak Terhadap Kinerja Sistem Informasi Akuntansi. Jurnal ULTIMA Accounting, 9(1), 60-78. https://doi.org/10.31937/akuntansi.v9i1.588

Doll, W. J. and Torkzadeh, G. (1988). The Measurement of End-User Computing Satisfaction, 12(2), pp.259-274.

Dwirandra, A. A. N. B., \& Astika, I. B. P. (2020). Impact Of Environmental Uncertainty, Trust And Information Technology On User Behavior Of Accounting Information Systems. Journal Of Asian Finance, Economics And Business,7(12),1215-1224. Https:/ / Doi.Org/10.13106/Jafeb.2020.Vol7.No12.1215

Dwitrayani, M. C., Widanaputra, A. A. G. P., \& Putri, I. G. A. M. A. D. (2017). Pengaruh Kecanggihan Teknologi Informasi, Partisipasi Manajemen, Budaya Organisasi Dan Kepuasan Pengguna Pada Efektivitas Sistem Informasi Akuntansi Bank Perkreditan Rakyat di Kabupaten Badung. EJurnal Ekonomi Dan Bisnis Universitas Udayana, 6(1), 197-222.

Gillespie \& Cecil. (1995). Accounting System Procedures and Methods, 3th edition, New Delhi. In Prentice Hall of India. Journal Of Management Information System

Govindarajan, V., \& Gupta, A. K. (1985). Linking control systems to business unit strategy: impact on performance. Accounting, Organizations and Society, 10(1), 51-66. https:/ / doi.org/10.1016/0361-3682(85)90031-5

Huber, G. P. (1990). A Theory of the Effects of Advanced Information Technologies on Organizational DeSign, Intelligence, and Decision Making. Academy of Management Review, 15(1), 47-71. https:/ / doi.org/10.5465/amr.1990.4308227

Ismail, N. A. (2009). Factors Influencing AIS Effectiveness Among Manufacturing SMEs: Evidence From Malaysia. The Electronic Journal of Information Systems in Developing Countries, 38(1), 1-19. https://doi.org/10.1002/j.16814835.2009.tb00273.x

Krahel, J. P., \& Vasarhelyi, M. A. (2014). AIS as a Facilitator of Accounting Change: Technology, Practice, and Education. Journal of Information Systems, 28(2), 115. https:// doi.org/10.2308/isys-10412

Masadeh, M. (2012). Training, Education, Development and Learning: What Is the Difference? European Scientific Journal, 8(10), 62-68. http://eujournal.org/index.php/esj/article/view/163

Medina, J., Victoria, C., Jiménez, D. K., Mora, A., Victoria, C., Ábrego, M. S. D., \& Victoria, C. (2014). Training in Accounting Information Systems for Users ' Satisfaction and Decision Making. 5(7), 134-144.

Moqbel, M. A. (2014). The Impact Of Accounting Information Systems (AIS) On ECommerce Analytical Study-Service Sector-Jordan ASE. Journal of Information Technology Management, 3(1), 62-80.

Nabizadeh, S. M., \& Omrani, S. A. (2014). Effective Factors on Accounting Information System Alignment; a Step towards Organizational Performance. International Journal of Scientific and Research Publications, 4(9), 
$1-5$.

Puspitasari, N. W. N. G. J. (2017). Keterlibatan Dan Kemampuan Teknik Personal Pada Kinerja Sia Dengan Pendidikan Dan Pelatihan Sebagai Variabel Moderasi. E-Jurnal Akuntansi, 2017(1), 380-408.

Putra, P. B. V. K. (2021). Kecanggihan Teknologi dan Efektivitas Penggunaan Sistem Informasi Akuntansi dengan Kemampuan Teknik Personal dan Pelatihan sebagai Variabel Pemoderasi. 31(1), 233-245.

Putri, N. W. I. D. (2015). Pengaruh Kemampuan Teknik Personal , Program Pelatihan Dan Pendidikan, Insentif , Penerapan Sia. Akuntansi, 3, 582-592.

Putu Ardiwinata, I. G. N., \& Sujana, I. K. (2019). Pengaruh Kemampuan Teknik Personal, Keterlibatan Pemakai, Pelatihan Dan Pendidikan Pada Kinerja Sistem Informasi Akuntansi. E-Jurnal Akuntansi, 27, 1867. https://doi.org/10.24843/eja.2019.v27.i03.p09

Ratnaningsih, K., \& Suaryana, I. (2014). Pengaruh Kecanggihan Teknologi Informasi, Partisipasi Manajemen, Dan Pengetahuan Manajer Akuntansi Pada Efektivitas Sistem Informasi Akuntansi. E-Jurnal Akuntansi, 6(1), 1-16. https://ocs.unud.ac.id/index.php/Akuntansi/article/view/7775

Rokhman, S. (2016). Pengaruh Kecanggihan Tegnologi Informasi, Partisipasi Manajemen, Pengetahuan Manajer Akuntansi, Dan Komitmen Organisasional Pada Efektifitas Sistem Informasi Akuntansi.

Ruth, T. (2018). Pengaruh Kemampuan Teknik Personal, Pelatihan dan Pendidikan terhadap Efektivitas Penggunaan SIA Pada Rumah Sakit. E-Jurnal Akuntansi, 22(2), 1419-1444. https:// doi.org/10.24843/EJA.2018.v22.i02.p22

Seviani, E. (2017). Pengaruh Kecanggihan Teknologi Informasi, Partisipasi Manajemen, Dan Pengetahuan Manajer Akuntansi Pada Efektivitas Sistem Informasi Akuntansi (Survei. Https://Ci.Nii.Ac.Jp/Naid/40021243259/

Spremic, M[Ario] \& Jakovic, B. (2012). The Impact Of The Accounting Information System Usage On Companys ' E-Business Efficiency. 23(1), 1067-1070.

Suartika, K. A., Luh, N., \& Widhiyani, S. (2017). Kemampuan Teknik Personal Pada Efektivitas Penggunaan Sistem Informasi Akuntansi dengan Pendidikan Dan Pelatihan Sebagai Pemoderasi. E-Jurnal Akuntansi, 18(2), 1485-1512.

Wulandari, N. P. W., \& Utama, I. M. K. (2016). Reputasi Kantor Akuntan Publik Sebagai Pemoderasi Pengaruh Profitabilitas Dan Solvabilitas Pada Audit Delay. E-Jurnal Akuntansi Universitas Udayana, 17(2), 1455-1484.

Yesa, T. A. P. (2016). Pengaruh Partisipasi Pemakai Terhadap Kinerja Sistem Informasi Akuntansi. E-Jurnal Akuntansi, 15(2), 1482-1509. 